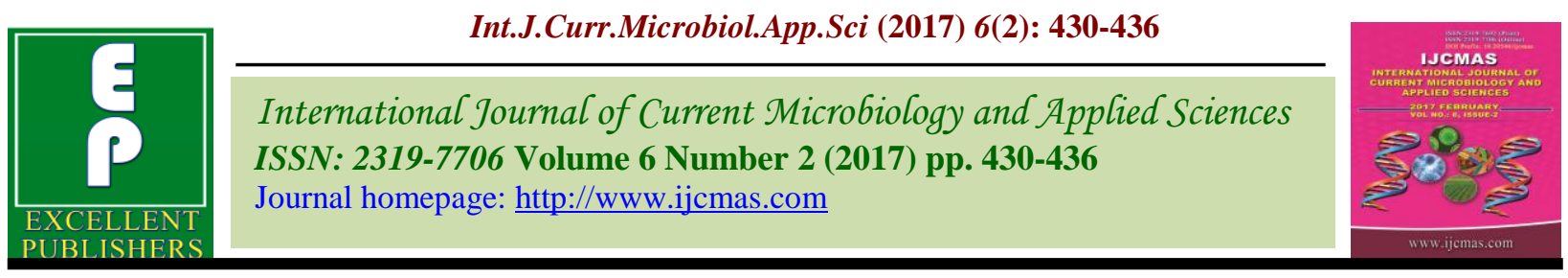

Original Research Article

http://dx.doi.org/10.20546/ijcmas.2017.602.048

\title{
Assessment of Casing Mixtures on Yield Potential and Quality of Button Mushroom (Agaricus bisporus) - On Farm Trial
}

\author{
Arvind Preet Kaur* and Vipan Kumar Rampal
}

Krishi Vigyan Kendra, Shamsher Nagar - Sirhind, Distric: Fatehgarh Sahib, Punjab Agricultural

University - Ludhiana (Punjab), India

*Corresponding author

\section{A B S T R A C T}

Keywords

Agaricus bisporus, casing mixtures, growth parameters, yield.

\section{Article Info}

Accepted: 12 January 2017 Available Online: 10 February 2017
Supplementation of substrate at casing to increase the yield and quality of mushroom [Agaricus bisporus] is an important practice in commercial production of white button mushroom. This project was done to study the effect of different casing mixtures on the growth and yield of common button mushroom (Agaricus bisporus). There were significant differences between different casing mixtures compositions. The highest total yield $(1066.97 \mathrm{~g})$ was obtained from casing mixture, CCP + RH + Formaline + RS and lowest yield $(607.93 \mathrm{~g})$ was obtained from FYM+SS+Formaline. The second highest yield $(646.57 \mathrm{~g})$ was obtained from $\mathrm{FYM}+\mathrm{SS}+\mathrm{RH}+$ Formaline casing mixture. Also the application of casing mixture $\mathrm{CCP}+\mathrm{RH}+$ formaline $+\mathrm{RS}$ (1:1:1) differed significantly in time taken for harvesting of first, second and third flush with that of other casing mixtures. Finally all the casing materials were evaluated for their effect on growth parameters and yield of Agaricus bisporus. Among the different casing mixture tested CCP $+\mathrm{RH}+$ Formaline $+\mathrm{RS}$ was found to be better in yield when compared to other casing mixtures. These studies will help the mushroom growers for selecting the most suitable casing materials for better growth behaviour and optimum yield potential of common button mushroom (A. bisporus) grown in our country

\section{Introduction}

The button mushroom [Agaricus bisporus (Lange) Sing] is the most widely cultivated and consumed mushroom throughout the world and India includes about $40 \%$ of total world mushroom production (Giri and Prasad 2007). The button mushroom will grow on composted substrates made from various materials (Delphina and Royse, 2008). The compost in which it grows vegetatively, and the nutritionally poor casing materials, provides suitable physical, chemical and biological conditions that stimulate initiation of fruiting body formation (Gerrits, 1974).
Punjab is blessed with suitable agro-climatic conditions for the production of different types of mushrooms. Mushrooms are considered to be healthy food because of their relatively high and qualitatively good protein content and also because of the presence of good vitamins, minerals and low fat content (Verma et al., 1987) reported that mushrooms are very useful for vegetarian diet because they contain some essential amino acids which are mostly found in animal proteins. In this context mushroom cultivation represent one of the economically viable processes for 
the bioconversion of agricultural and agroindustrial wastes into a protein rich food, making it a potent weapon against malnutrition in developing countries like India which has lowest per capita consumption of protein in the world (Sohi, 1982; Wood, 1989; Chang and Miles, 1989; Buswell and Chang, 1993). Button mushroom is one of the largely grown mushrooms and has the good demand in the market and world trade too.

Agaricus bisporus requires two different substrates to form the fruiting bodies i.e. the compost for nutrition on which it grows vegetatively and the casing soil in which the suitable physicochemical/biological conditions stimulate the initiation process of pin head formation for fruit body production. In spite of being nutritionally deficient medium, casing layer plays an important role in the production of button mushroom. The casing layer is one of the important growing parameter and source of variation in production, quality and uniformity of commercial cropping. Among the variety of casing materials, use of farmyard manure (FYM) as casing medium for mushroom cultivation has been in vogue in Indian subcontinent because of its easy availability.

Although many different materials may function as a casing layer, coco peat is generally regarded as the most suitable. Because of its unique water holding and structural properties, it is widely accepted as an ideal for casing.

Coco peat has a neutral $\mathrm{pH}$ and because of its organic content and granular structure, stays porous even after a succession of watering, holds moisture, allows appropriate gaseous exchanges and supports microbial population able to release hormone-like substances which are likely involved in stimulating the initiation of fruit bodies (Eger, 1972; Hayes, 1981).
Keeping this view in mind the choice of the farmers for growing of button mushroom depends on easily and locally available casing mixtures. Bhatt et al., 2006 evaluated seven different casing mixtures prepared from 5 materials viz., FYM, spent compost, vermicompost, coir pith and press mud, for their yield potential on $A$. bisporus. In a similar studies Dhar et al., (2006) also reported effect of casing materials on the yield and quality of the fruiting body of button mushroom (A. bisporus). Huge quantities of farmyard manure, vermicompost, saw dust and other organic wastes are generated annually through the activities of agricultural, forest and food processing industries. Mushroom yield can be increased if these locally available casing mixtures are used to produce button mushrooms. Therefore, present investigation was carried out to see the effect of different casing mixtures on the yield potential and growth parameters of button mushroom $(A$. bisporus).

\section{Materials and Methods}

In order to study the effect of different casing mixtures on the growth and yield of common button mushroom (Agaricus bisporus) an On Farm Trial was carried out at farmer's mushroom units during two successive years i. e. 2014-15 and 2015-16 with three casing mixture formulations i.e by Krishi Vigyan Kendra, Fatehgarh Sahib, Punjab Agricultural University Ludhiana. The experiment was set up in a Completely Randomized Design with 3 replications.

\section{Compost preparation}

For the basic materials for compost, wheat straw was collected from Krishi Vigyan Kendra, Fatehgarh Sahib. Other ingredients like wheat bran, urea, potassium (Murate of Potash), phosphorus (Single Super 
Phosphate), gypsum, molasses and lindane were procured from market.

The compost was prepared by long method of composting (LMC), using the method recommended by Punjab Agricultural
University, Ludhiana. Wetted wheat straw was spread thinly over entire floor of the composting yard and then gradually wetted by sprinkling water, till the straw was taking no more water.

Formulation of the compost for button mushroom

\begin{tabular}{|c|c|}
\hline Ingredients & Quantity \\
\hline Wheat straw & $300 \mathrm{~kg}$ \\
\hline Calcium ammonium nitrate & $09 \mathrm{~kg}$ \\
\hline Urea & $03 \mathrm{Kg}$ \\
\hline Superphosphate & $03 \mathrm{Kg}$ \\
\hline Murate of potash or potassium sulphate & $03 \mathrm{~kg}$ \\
\hline Wheat bran & $15 \mathrm{~kg}$ \\
\hline Seera (molasses) & $05 \mathrm{~kg}$ \\
\hline Gypsum & $30 \mathrm{~kg}$ \\
\hline Gamma BHC (20 EC) & $60 \mathrm{ml}$ \\
\hline Furadon (3 G) & $150 \mathrm{gm}$ \\
\hline
\end{tabular}

The straw was then turned for even wetting at this stage and water content was maintained at 75 per cent. The moist straw was mixed with wheat bran and fertilizers uniformly scattered over the straw. A heap was made after each turning but not compressed tightly so as to maintain the aerobic condition in the compost heap. Gypsum was mixed at the third turning. Gamma BHC was mixed at 7th turning. Total seven turnings were done, first three turnings at four days interval and last four turnings were done at 03 days interval. The compost was then ready for spawning i.e. it was dark brown in colour and without any smell of ammonia and had sufficient moisture content (68-70\%) when pressed between the palms.

\section{Spawning}

The compost was mixed with mushroom spawn at $2.5 \mathrm{~kg} /$ quintal compost and spawned compost was filled $(10 \mathrm{~kg} / \mathrm{bag})$ in a cylindrical polythene bag (size $40 \times 40 \mathrm{~cm}$ ) and compost filled bags were covered with newspaper sheets to prevent loss of moisture content from mushroom beds, placed in growing chamber, where temperature ranged between $22-28^{\circ} \mathrm{C}$ (Ram and Holkar, 2010).

\section{Preparation of casing mixtures}

The selected basic material for preparation of casing soil, casing materials were obtained from local market.

Three casing mixture formulations were used as casing for investigations.

$\mathrm{T} 1$ : Cocopeat + rice husk + formaline + red soil $(1: 1: 1)$

T2: Farmyard manure + sandy soil + formaline (1:1:1)

T3: Farmyard manure + sandy soil + rice husk + formaline $(1: 1: 1: 1)$

Rice husk, cocopeat and soil were sterilized in a horizontal autoclave at a temperature of 121 ${ }^{\circ} \mathrm{C}$ for 20 minutes. Sterilized casing materials were taken out to cool down at room temperature by spreading on well cleaned cemented floor. 


\section{Casing}

After full spawn run or full mycelia colonization of the compost, the casing materials were applied on top of the compost at a uniform thickness of one inch. Each of the casing materials was applied to three uniform bags (replicates) containing $15 \mathrm{~cm}$ deep of spawned compost. The nine bags are arranged in a Completely Randomized Design (CRD) in a covered mushroom growing room. Each bag received 0.5 to 1.0 litre of water as irrigation once every other day, the rate being based on the relative dryness of the casing material. Mushroom beds were sprayed regularly with water to keep the casing soil adequately moist. The recorded temperature of cropping room was ranged $18-24^{\circ} \mathrm{C}$ during harvesting period.

Observations recorded in each bag on the following parameters.

i. Days to first, second and third flushes (Days after spawning)

ii. Duration of three flushes.

iii. Mean yields of mushroom (fresh weight in gms)for each of the first three flushes.

iv. Total yield of mushroom (fresh weight in gms) per treatment from the first three flushes.

Each treatment was replicated three times and the yield data were statistically analyzed by Complete Randomized Design (CRD).

\section{Results and Discussion}

Mushroom bags were completely colonized by mushroom mycelium within 20 days and then covered by different casing soil for following observation of growth stages.

\section{Yields of button mushroom}

There were significant differences in the yield of button mushroom obtained from three flushes. It is evident from the Table 1 that the highest yield of first flush was obtained from the casing mixture of $\mathrm{CCP}+\mathrm{RH}+$ Formaline + RS (366.67 g) followed by FYM + SS+ Formaline, FYM + SS + RH + Formaline (183.33 and $196.67 \mathrm{~g})$, respectively. Casing mixture CCP + RH + Formaline + RS showed the highest $(402.00 \mathrm{~g})$ yield whereas FYM + SS+ Formaline $(226.00 \mathrm{~g})$ showed lowest yield in the harvesting of second flush. In the 3rd flush, maximum yield was obtained from casing CCP + RH + Formaline + RS (298.3 g) where as lowest yield was obtained from FYM+SS+ Formaline (198.6 g).

The highest total yield (1066.97 g) was obtained from casing mixture, $\mathrm{CCP}+\mathrm{RH}+$ Formaline + RS and lowest yield $(607.93 \mathrm{~g})$ was obtained from FYM + SS + Formaline. The second highest yield $(646.57 \mathrm{~g})$ was obtained from FYM + SS + RH + Formaline casing mixture.

The casing mixture of $\mathrm{CCP}+\mathrm{RH}+$ Formaline + RS produced higher total yields than the other two treatments due to improvement of aeration by addition of coco peat to red soil and as compared to sandy soil, red soil has high water holding capacity. Its moisture holding capacity is such that it can be watered without sealing off the compost. Carbon dioxide (and other gases), formed in the compost during spawn running and fruiting, and these must be able to escape through the casing. Effects of high carbon dioxide concentration include production of small caps and elongation of stipe. The low yields recorded in FYM + SS + Formaline casing, may be attributed not only to its inability to hold sufficient moisture but also the rapid rate at which it loses it by infiltration and evaporation. Water instead of just wetting the casing, may have been draining down into the compost thereby causing sogginess, which interferes with mycelia development and 
performance. On the other hand, low yield low yield obtained in the study can be attributed to the delay in casing which encouraged the occurrence of pests such as mushroom flies, mites and competitive weeds. Low yield encountered can also be attributed to inability to adequate mitigate (control) environmental conditions such as temperature and humidity in the growing room.

Similar results are recorded by Chandra et al., (2014) that revealed that casing mixture CCP $+\mathrm{VC}+\mathrm{FYM}+\mathrm{SD}+$ Sand recorded the highest yield (320 g) whereas CCP + FYM ( $250 \mathrm{~g}$ ) showed lowest yield in the harvesting of second flush. The total highest yield $(1112.26 \mathrm{~g})$ was obtained from casing mixture, $\mathrm{CCP}+\mathrm{VC}+\mathrm{FYM}+\mathrm{SD}+$ Sand and lowest yield $(736.67 \mathrm{~g})$ from CCP + FYM. Casing mixture of $\mathrm{CCP}+\mathrm{FYM}+\mathrm{SD}$ recorded second highest yield (1033.67 g).

This finding was in accordance with the result of Dhar et al., (2006) who used eight commonly available casing materials in India viz., FYM, SMC, CCP, MG, VC, TerracareA, Terracare-B and FYM + SMC to identify the suitable casing materials for use in button mushroom cultivation. Coir pith results in early pinning and significantly higher number of fruit bodies and total yield. Our result also confirmed the findings of Pardo et al., (2004) who evaluated different casing materials for the cultivation of button mushroom.

All the casing materials were evaluated for their effect on growth parameters and yield of Agaricus bisporus. Among the casing mixtures, $\mathrm{CCP}+\mathrm{VC}+\mathrm{FYM}+\mathrm{SD}+$ Sand and $\mathrm{CCP}+\mathrm{FYM}+\mathrm{SD}$ were found to be better in yield compared to other casing mixtures.

Also, Eslaminezhad et al., 2015 concluded that the maximum first yield $(492.96 \mathrm{~g} / \mathrm{g})$ was observed in the use casing supplemented with $2.5 \%$ of soybean meal. Casing combined with $1 / 2$ Hogland solution had the highest total yield $(1121.71 \mathrm{~g} / \mathrm{g})$.

Table.1 Mean yields per flush and total yields (g) of button mushroom per treatment.

\begin{tabular}{|c|c|c|c|c|c|}
\hline Casing Mixtures & No. of flushes & $\mathbf{1}^{\text {st }}$ Flush & $\mathbf{2}^{\text {nd }}$ Flush & $\mathbf{3}^{\text {rd }}$ Flush & Total yield (g) \\
\hline $\begin{array}{c}\text { CCP+RH+formaline+RS } \\
(1: 1: 1)\end{array}$ & 3 & 366.67 & 402.00 & 298.3 & 1066.97 \\
\hline FYM+SS+formaline (1:1:1) & 3 & 183.33 & 226.00 & 198.6 & 607.93 \\
\hline $\begin{array}{c}\text { FYM+SS+RH+Formaline } \\
(\mathbf{1 : 1 : 1 : 1 )}\end{array}$ & 3 & 196.67 & 233.3 & 216.6 & 646.57 \\
\hline CD (p=0.05) & - & 23.8 & 41.4 & 27.1 & - \\
\hline
\end{tabular}

$\mathrm{CCP}=$ Cocopeat; FYM = Farmyard Manure; RH = Rice Husk; SS = Sandy soil

Table.2 Mean duration and days to each flush of button mushroom per treatment

\begin{tabular}{|c|c|c|c|c|c|}
\hline Casing Mixtures & $\begin{array}{c}\text { No. of } \\
\text { flushes }\end{array}$ & $\begin{array}{c}\text { Days to Initiation } \\
\text { of pin head }\end{array}$ & $\begin{array}{c}\text { Days to 1 } \\
\text { Flush }\end{array}$ & $\begin{array}{c}\text { Days to 2 } \\
\text { Flush }\end{array}$ & $\begin{array}{c}\text { Days to 3 }^{\text {rd }} \\
\text { Flush }^{\text {plush }}\end{array}$ \\
\hline CCP+RH+formaline+RS (1:1:1) & 3 & 35.00 & 40.67 & 60.33 & 85.00 \\
\hline FYM+SS+formaline (1:1:1) & 3 & 38.67 & 43.33 & 62.67 & 76.67 \\
\hline FYM+SS+RH+formalie (1:1:1:1) & 3 & 36.33 & 42.67 & 60.33 & 76.67 \\
\hline CD (p=0.05) & & 6.90 & 2.41 & 3.30 & 4.07 \\
\hline
\end{tabular}

$\mathrm{CCP}=$ Cocopeat; FYM= Farmyard Manure; RH= Rice Husk; SS= Sandy soil

Harvesting of flushes: Days recorded after spawning 


\section{Initiation of pin head}

Data pertaining to the time taken for initiation of pin heads are presented in Table 2. The casing mixture of FYM + SS + Formaline took maximum time (i.e. 38.67 days) while $\mathrm{CCP}+\mathrm{RH}+$ Formaline + RS (1:1:1) took minimum time period (i.e.35 days). These casing mixtures differed significantly among themselves.

\section{Time taken for harvesting of different flushes}

The harvesting of first flush ranged between (40.67 to 43.33 days). It is evident from the Table 2 that application of two casing mixture $\mathrm{CCP}+\mathrm{RH}+$ Formaline + RS $(1: 1: 1)$ and $\mathrm{CCP}+\mathrm{RH}+$ Formaline + RS (1:1:1) showed significant difference in time taken for harvesting of first flush. The casing mixture $\mathrm{CCP}+\mathrm{RH}+$ Formaline $+\mathrm{RS}$ was taken minimum time (40.67 days) for harvesting of first flush and maximum time (43.33 days) by application of FYM + SS + Formaline.

The harvesting of second flush in two casing mixture i.e. $\mathrm{CCP}+\mathrm{RH}+$ Formaline $+\mathrm{RS}$ $(1: 1: 1)$ and FYM + SS + RH + Formaline (1:1:1:1) took the same time period $(60.33$ days) and these casing mixture differed nonsignificantly among themselves. The range of time taken for harvesting second flush was found between 60.33 and 62.67 days. Third flush was harvested in the range of 76.67 to 85.00 days on various casing mixtures.

Application of casing mixture $\mathrm{CCP}+\mathrm{RH}+$ Formaline + RS (1:1:1) differed significantly in time taken for harvesting of third flush with that of other casing mixtures. The performance of casing $\mathrm{CCP}+\mathrm{RH}+$ Formaline + RS (1:1:1) was better than other casing mixture. This may be due to the reason that it absorbs water quickly and releases it slowly (by evaporation). If the material permits the applied water to run straight through it (as will sand), the surface of the compost will become waterlogged and useless. Thus, it may be concluded that the type and nature of soil influences many of the management practices, particularly in relation to watering and ventilation. In its excavation and preparation for use as a casing layer, particular care is required to maintain structure. Soils with a good proportion of clay and not much sand have the best physical properties (Chang and Hayes, 1978). The finding of present study will help the farmers for selection and better utilization of locally available casing materials for obtaining higher yield of button mushroom (A. bisporus) to increase their income.

\section{References}

Bhatt, P., Kushwaha, K.P.S., Singh, R.P. 2006. Physico-chemical properties of different casing mixtures and its effect on yield of Agaricus bisp. Mush. Res., 15(1): 29-32.

Buswell, J.A. and Chang, S.T. 1993. Edible mushrooms attributes and applications. In: Genetics and breeding of edible mushrooms. Buswell J. A. and Miles P. G. (Eds). Gordon and Breach Philadelphia, pp. 297-394. Evaluation of quantitative and qualitative production parameters. Spanish J. Agril. Res., 2(2): 267-272.

Chandra, R., Pandey, V.N. and Singh, M.H.B. 2014. Comparative evaluation of casing mixtures on the yield potential of button mushroom (agaricus bisporus). Proceedings of the 8th International Conference on Mushroom Biology and Mushroom Products (ICMBMP8) pg. 345-350.

Chang, S.T. and Miles, P.G. 1989. Edible mushroom and their cultivation. Florida. CRC Press.

Chang, S.T. and Hayes, W.A. 1978. The 
biology and cultivation of edible mushroom, Academic Press.New York. USA.

Delphina, P.M. and Royse, D.J. 2008. The influence of spawn type and strain on yield, size and mushroom solids content of Agaricus bisporus produced on noncomposted and spent mushroom compost. Biores. Technol., 99: 32053212 .

Dhar, B.L., Gupta, O.P., Raj. D. 2006. Casing layer as related to mushroom yield and quality in Agaricus bisporus in India. Mush. Res., 15(2): 111- 123.

Dhar, B.L., Ahlawat, O.P., Gupta, Y. 2003. Evaluation of Agro-industrial wastes as casing materials in Agaricus bisporus cultivation in India. Mush. Int., 92: 5-9.

Eger, G. 1972. Experiments and comments on the action of bacteria on sphorophore initation in Agaricusbisporus. Mush. Sci., 8: 719-725.

Eslaminezhad, Z., Emaratpardaz, M. J., Panahandeh, J. 2015. The effect of nutritional supplement addition and use of casing overlay to substrate on yield of oyster mushroom (Pleurotusflorida). Int. J. Agri. \& Agri. Res., 7(4): 61-67

Giri, S.K. and Prasad, S. 2007. Drying kinetics and rehydration characteristics of microwave vacuum and convective hot-air dried mushrooms. J. Food Engin., 78: 512-521.

Gerrits, J.P.G. 1974. Development of a synthetic com- post for mushroom growing based on wheat straw and chicken manure. Nether. J. Agri. Sci., 22: $175-194$.

Hayes, W.A. 1981. Interrelated studies of physical, chemical and biological factors in casing soils and relationships with productivity in commercial culture of Agari- cusbisporus. Mus. Sci., 11: 103-129.

Pardo, A., De Juan, A.J., Pardo, J. 2004. Assessment of different casing materials for use as peat alternatives in mushroom cultivation. Evaluation of quantitative and qualitative production parameters. Spanish J. Agril. Res., 2(2): 267-272-

Ram, R.C. and Holkar, S.K. 2010. Bioefficacy of casing materials for growth stages physical parameters and yield of Agaricusbisporus (Lange). Imbach 2010. Inter. J Mush. Res., 18(1): 65-68.

Sanchez, C. 2004. Modern aspects of mushroom culture technology, Appl. Microbiol. Biotechnol., 64: 756-762.

Sohi, H.S. 1982. Role of edible mushroom in recycling of agricultural waste and as an alternative protein source: present status of mushroom cultivation in India. Front. Res. Agri., S.K. Roy (ed.): ISI Calcutta, 565-579.

Verma, R.N., Singh, G.B., Bilgrami, K.S. 1987. Fleshy fungal flora of N. E. H. India- I. Manipur and Meghalaya. Indian Mush. Sci., 2: 414- 421.

Wood, D.A. 1989. Mushroom biotechnology. Inter. Indust. Biotechol., 25: 213-220.

\section{How to cite this article:}

Arvind Preet Kaur and Vipan Kumar Rampal. 2017. Assessment of Casing Mixtures on Yield Potential and Quality of Button Mushroom (Agaricus Bisporus) - On Farm Trial. Int.J.Curr.Microbiol.App.Sci. 6(2): 430-436. doi: http://dx.doi.org/10.20546/ijcmas.2017.602.048 